\title{
Is the Age of Party Democracy Over or Are Parties Entering a New Renaissance?
}

\author{
Da-chi Liao ${ }^{1}$, Jiun-Chi Lin², Michael J. Jensen ${ }^{3 *}$ \\ ${ }^{1}$ Professor, Institute of Political Science, National Sun Yat-sen University, Taiwan \\ ${ }^{2}$ Ph.D. student, Institute of Political Science, National Sun Yat-sen University, Taiwan \\ ${ }^{3}$ Senior Research Fellow, Institute for Governance and Policy Analysis, University of Canberra \\ *Corresponding Author: Michael J. Jensen, Senior Research Fellow, Institute for Governance and \\ Policy Analysis, University of Canberra, Taiwan

\begin{abstract}
Many scholars pointed out that the role of political parties has been declining in democratic countries. However, with the prevalence of digital media, does digital media become a new channel for parties to rebuild its relation to people? This paper aims to discuss the relationship between political parties and digital media. This paper examines our research questions by analyzing Facebook page data of Spanish party Podemos and Taiwanese party New Power Party (NPP). Both parties are selected based on a most different systems approach and have contested at least one national election. Results show two findings. Firstly, in the beginning, both parties have a low level of commenting in relation to liking. However, the level of commenting on Podemos page increases. It tells that both parties are not more dialogical in the launch phase. Secondly, results show that Podemos replies more often than NPP in times between party launch and the entry into its first campaign.
\end{abstract}

Keywords: Podemos, New Power Party (NPP), connective party, Facebook.

\section{INTRODUCTION}

Schattschneider $(1942,1)$ famously declared that "political parties created democracy and ... modern democracy is unthinkable save in terms of ... parties." But if parties are the fundamental linking mechanism between citizens and governments (Budge and Keman 1993; Dalton, Farrell, and McAllister 2011), democracy today may be in shambles across much of the developed world. Political parties face declining levels of membership (Biezen and Poguntke 2014; Van Biezen, Mair, and Poguntke 2012); trust in political parties by citizens is at critically low levels (Dalton and Wattenberg 2002); there is declining identification with political parties across advanced industrial democracies (Dalton 2013; Mair 2013); parties are increasingly reliant on professional staffers rather than their members for the development of campaign messaging, policies, strategies, and tactics (Biezen and Poguntke 2014; Poguntke et al. 2016). Although citizens may today have multiple paths to participate in the life of parties outside of formal party membership (Scarrow 2015), to the extent that party supporters are reduced to retweeting party talking points and accepting their policy programs and the minimal political roles granted to them by parties. It is no wonder then that Peter Mair (2013)observed at the end of a long career studying party politics that parties today have become hollowed out of their popular participation.

Although political parties, particularly the established parties, have faced considerable declines in support, in some cases we have seen an explosion of new parties. In Spain, as already low levels of support for political parties continued to erode under the weight of the financial crisis, over 400 new parties have formed since 2010 (Tormey 2015). In Taiwan, the Sunflower movement has given rise to new parties and invigoration of many of its smaller parties in the face of declining trust in the KMT which has dominated Taiwanese politics since the period of democratization (Ho and Huang 2017; Rigger 2016). Under these conditions, there have been two predominant responses: the rise of populist parties which align themselves against the incumbent elites and connective parties which search for new ways to reconnect citizens with political life. 
The emergence of new parties in these spaces have involved extensive use of digital media, in particular social media channels to connect with supporters given the low costs associated with communication and in some cases the potential for a dialogical engagement with supporters. This paper examines the role of social media technologies in shaping the structure of the relationship between parties/campaign organizations and supporters across ideologically diverse parties in during both campaign and noncampaign periods. Our contribution builds on but goes beyond the concept of multi-speed party membership(Scarrow 2015) as we are not interested so much in adumbrating a taxonomy of membership categories as we are in analyzing parties as a space where supporters may develop their own narratives and have an impact on party and campaign messaging. The research analyses two parties which emerged from movements which criticized the existing political system for a lack of spaces for participation in the democratic process, the New Power Party (NPP) in Taiwan and Podemos in Spain. The data show that during the first three months of the existence of these parties there is more democratic engagement on their Facebook pages than during the campaign periods before subsequent national elections over a year later.

\section{Connective Parties And Connective Technologies}

Historically, the distribution of communication technologies has been interwoven in the organizational capacities of societies and governing practices. Harold Innis (2007)observed that the creation of paper enabled the Egyptian empire to spread as the law could be more easily transported to distant locations. Modern political parties have emerged under a context where political communication was predominantly monological and hierarchical. In addition to the psychological needs for leadership and the practical needs for a division of political labor, Michels (1966) observed that parties were centralized in part because they retained a monopoly on the prevailing means of communication with party members. A broadcast era of politics expanded the range of information sources available, facilitating mobilization on grounds outside the terms of a partisan press (Dalton 1984; Inglehart 1970), yet the structure of these communications remained hierarchical. Digital technologies afford horizontal communication structures between organizations and members as well as between members (Bimber, Flanagin, and Stohl 2012).

Social media facilitate the creation of new political narratives independent of those legitimized by parties and other formal authorities as they provide independent spaces for the circulation of political communications (Jensen and Bang 2013, 2015). Political organization can be an effect of the sharing of these narratives binding persons together within the form of a connective political association (Bennett and Segerberg 2013).Although connective action was a logic originally developed as an account of the organizational form of certain types of social movements, this logic has been extended to other kinds of political organizations including relationships between citizens and parties as well as wider structures of governance (Bennett, Segerberg, and Knüpfer 2017; Chadwick and StromerGalley 2016; Jensen and Bang 2017). Two aspects which distinguish connective action logic from collective action logic. First, connective action involves the sharing of "broadly inclusive, easily personalized action frames" which form a basis for persons acting together (Bennett and Segerberg 2013, 2).This distinguishes connective action from a collective action logic which is organized around collective identities. And second, connectivity involves a reciprocal authority relationship between citizens and political officials such that an authority relationship would not exist without its acceptance by political authorities(Bennett and Segerberg 2013; Jensen and Bang 2018).Although much attention in the literature on connective action has concerned personalized action frames, the authority relationship has not received as much attention. We therefore concern ourselves with this relationship.

\subsection{Authority as Reciprocal Relationship}

Political authority has been treated as a special form of power exercised by those with specific roles concerning the day-to-day operation of a political system (Easton 1965). Traditional accounts of power in political science have emphasized that power is irreducibly a "power over" (Almond and Verba 1989; Castells 2009; Dahl 1957). On this view, political authority can only be a matter of a "Leviathan" lording over citizens (Bang 2003, 16). However, political authority always involves a reciprocal relation of acceptance - if there was broad refusal to accept the legitimacy an authority has over a population, that authority would cease to exist(Easton 1965, 19).Further, one may have good grounds to accept commands, laws, wishes, and so forth articulated by a ruler as it can be 
advantageous either as a practical matter of expediency or it may help one achieve something they otherwise could not. Authority has been accepted to the extent that it is taken as a premise for subsequent action(Bakhtin 1981; Easton 1965; Luhmann 1982).Acceptance of political authority may be a means for citizens to achievean end. However, in a connective party, we should see authority flow both directions - between the party organization and leaders and supporters as well as from the supporters to the party organization and leadership.

Although social media spaces may create digital architectures that afford two-way communications, it is an empirical question as to whether they do that in practice. In particular, it is a question as to whether supporters engage with parties and each other, the structure of these engagements, and whether parties engage with supporters. Each of these forms of communication have consequences for the creation of connective action communities within party spaces. We deal with each in turn.

First, party supporters may legitimate the positions of parties without adding their own narratives. Particularly during campaign periods, campaigns are thought to use digital media as a form of "controlled interactivity" which allows the similarcra of engagement without substantially threatening the coherence of the broadcast message from the campaign (Freelon 2017; Stromer-Galley 2014). The effect of that is to reinforce a monologic structure of communication from the party to the public. Such communications may take the form of a retweet or a Facebook like or share without additional commentary. These forms of communications amplify the reach of the party by further diffusing their communications without customizing or altering the message. Most research on the use of social media by parties has focused on political campaigning and the findings indicate that the bulk of social media campaigning by politicians and parties tends to be monologic in structure, taking on a form of broadcast or marketing rather than dialogue between supporters and political authorities (Enli 2015; Graham et al. 2013; Jensen 2017).

There is a question as to the extent this form of controlled interactivity prevails across different kinds of parties and at different time points. Michels argued that parties would inevitably move away from high levels of interactivity over time and evidence suggests that most parties are increasingly dependent on professionals rather than amateur supporters for their day-to-day operations (Poguntke et al. 2016). That may mean that parties follow a trajectory with higher levels of engagement during the "launch" phase of the party and then move towards more professional staffing and lower levels of engagement later in their development. Responding to party supporters is indicative of a horizontal power relation as it a) grants standing to the supporter who originally made an utterance and b) to the extent it is responsive, it grants their terms for discussion (Bakhtin 1981; Jensen 2017). A common criticism of the use of digital media is that they are used by political campaigns mostly to broadcast their positions rather than engage with supporters (Kreiss 2012; Stromer-Galley 2014). Architecturally, social media platforms like Twitter or Facebook allow for replies and dialogical engagement but it is an open question as to the extent to which they reply to supporters and under what conditions.

There is a difference between empowering party supporters with roles which are consequential for party messaging, strategies, and tactics, and listening to them in the form of poll or focus grouptesting slogans. The latter is indicative of a party's search for ways to move supporters to participate on the terms of the party rather than supporters participating on their own terms. Podemos, which emerged from the $15 \mathrm{M}$ movement in Spain, a movement which called for greater democratization in Spanish political life, significantly underperformed in its first contest for the Spanish parliament. It is though that this may be in part because the party had turned away from listening to the movement and relied during the campaign on professionalized messaging and strategies (Casero-Ripollés, Feenstra, and Tormey 2016). Hence our first research question inquires:

$\mathrm{RQ}_{1}$ : Are parties more dialogical in the launch phase of its existence than they are during election campaigns?

Second, the structure of communications between party supporters indicates whether supporters are able to form a space of communication independent of the party messaging. While party supporters may be repeating campaign talking points within these spaces, the fact that they are active suggests that a) there is the minimal possibility that alternative narratives are being forged and b) that social media platforms provide meaningful spaces of engagement between party supporters independent of the party itself. When party supporters respond to each other, they are open not just to the terms of 
debate created by the party posts but to the terms of debate created by their fellow citizens. These spaces may be dominated by a small group of individuals which makes them less egalitarian or there may be wide debates participated on equal terms. To the extent that they are more egalitarian, the deliberation is more inclusive (Dryzek 2009). Much communication research suggests that the digital world is divided into a power law distribution where there are a few influential users and a long tail (Hindman 2009; Konieczny 2009; Weeks, Ardèvol-Abreu, and Gil de Zúñiga 2017). Our second research question concerns,

$\mathrm{RQ}_{2}$ : Does the structure of interactions change from the early phases of the party to the time of its first national electoral contest?

\section{DATA AND Methods}

We analyze connective parties in relation to the differences in party systems, selecting cases on the basis of a most different systems approach. We select parties two different countries: Spain and Taiwan. These countries each have a party premised on different critiques of the democratic nature of the mainstream parties which captures and draws upon Mair's (2013) notion that parties have become uncoupled from citizens. Podemos in many ways grew out of the $15 \mathrm{M}$ movement which popularized a demand for "real democracy now" (Tormey 2015)and the NPP in Taiwan grew out of the Sunflower movement which sought to increase transparency in parliament (Thinking Taiwan 2015).Both of these parties represent political projects that, at least in their origins, aimed to reconnect party leaders and organizations with lay supporters.

The selection of these cases enables the investigation of the relationships between party systems and party organization. Lijphart (2012) has differentiated party systems in terms of majoritarian and consensus party systems. Majoritarian systems tend to be highly centralized and operate in termsof pluralities. Therefore, they are less inclusive than consensus systems which tend to have more parties occupying legislative assemblies. These party systems vary in three respects along the majoritarian and consensus dimension. First, they vary with respect to the effective number of parties in each case with Taiwan having been dominated by essentially 1-2 parties over time (Liao et al. 2015)while Spain has been predominantly a two-party dominant system with a variety of regional parties(Lijphart 2012). Second, these cases vary in terms of their level of federalism. Spain affords varying levels of independence to its 17 autonomous communities and two autonomous city jurisdictions while Taiwan has a centralized structure.

Finally, these cases are distinguished in terms of the cleavage structure. While Spain have a familiar left-right cleavage structure which has strained under varying degrees of neoliberalism, the salient political divide in Taiwan has remained one of unification-independence and the NPP has been one of the most vocal parties for independence. Taiwan has carried out neoliberal policies at the hands of both of the major parties (Chen and Li 2011; Hsu 2009); however, the salience of these policies have remained in the shadow of the dominant unification-independence cleavage and the attendant identity issues they bring to the fore (Hsieh 2005; McAllister 2016; Tsai 2016). Although the unificationindependence debate may also implicate concerns about the Taiwanese economy, unlike the Spanish case, this cleavage is not itself a matter of the kind of involvement that a government should have in the operation of the economy. It reflects an identity position which is distinct from the ideological differentiation of preferences. This distinction is relevant because in the Western world, parties emerged from the political organization of social cleavages as vehicles to represent group interests (Lipset and Rokkan 1967). By contrast, Taiwanese political parties politicize identity positions. Whereas, the $15 \mathrm{M}$ movement emerged independently of traditional movement organizations in Spain such as labor unions or religious groups, there is not the same level of organization around the unification-independence cleavage in Taiwan. This distinction then suggests that Spain might represent a harder case for a connective party given a tradition of ties between parties and civil society as mechanisms of political mobilization whereas in Taiwan the historical connection between parties and supporters is based on a political rather than social identity. As connective action involves a political rather than social identity (Jensen and Bang 2015, 2018), Taiwan would appear more ripe for connective action.

In this first part of the study, we analyze the first part of connective action, whether supporters simply provide legitimation for the communications of the party or if they provide their own content in the form comments on party communications. We study party and campaign supporter messaging using 
the comments left on Facebook posts. We select Facebook posts as Facebook has the highest level of uptake among social media platforms in the countries we are interested in(Chaffey 2017) and the communications on platforms like Twitter are often dominated by journalists and political elites making them less represented of communications articulated by ordinary citizens (Davis, HoltzBacha, and Just 2017).

We collected data on the Podemos and NPP pages from their point of inception in 2014 and 2015, respectively, up through August 2017. There were 1,789 posts and 118,406 comments collected on the NPP page between 2015 and 2017. The Podemos page contains 7,147 posts and592,167 comments from January 2014 through August 2017. Comments and replies were limited to those which are public but represent over $80 \%$ of all comments and replies on these pages.

This research examines two aspects of the engagement with these parties on their Facebook pages with respect to aspects of connectivity. The first is whether the engagement merely legitimates the position of the party or whether it at least potentially contains the communicative basis for the creation of independent narratives. We measure this in two ways. First, we differentiate between likes on party page posts and comments on those posts from supporters. Likes legitimate the party position whereas comments contain at least the potential for personalization. Second, we examine the extent to which these comments are dominated by a small set of persons or if there is evidence of relatively equal participation. To the extent that these are dominated by a small set of persons, the discussions are less inclusive. Communication concentration is measured by indices of inequality: the Gini coefficient as well as Thiel's measure of entropy and Shannon's measures of entropy. There is no single measure of concentration that is recognized as superior for measuring the level of dispersion in a field of communication. However, these measures have been used previously to estimate the level of concentration in spaces of digital communications (Hindman 2009)and, to the extent they provide similar results, we can be confident in our inferences about the level of concentration in Facebook comments.

There are two categories of communication which provide evidence of connective action: the communications shared between supporters of the party and the extent to which those communications become the basis for subsequent messaging by the party. In relation to party supporters, connective action is characterized by the sharing of personalized frames problematizing a state of affairs as well as pointing towards pathways for action (Bennett and Segerberg 2013; Jensen and Bang 2015). That includes a personalized diagnostic component as well as an action planlinked to the capacity of citizens individually and together to make a difference in a situation. Personalized frames are distinct from the frames which the parties use, though they may be picked up by the party at a later point in time. For this reason, we analyze the engagement on these pages in two ways. First, as the creation of distinct personalized action frames requires that persons articulate distinct frames, at a minimum, connective parties are characterized by more commenting than less connective parties. On the other hand, cartel parties do not require such input from supporters. Support for those parties is more a matter of agreement with the messaging, policies, strategies, and tactics of the party.

\section{RESUlts}

Both of these parties have contested at least one national election. Spain's Podemos party has contested all levels of elections, shocking the political establishment by coming in third in the 2014 European Union elections on May 25, 2014, just months after the party formed. Podemos likewise came in third place in the subsequent national parliamentary elections in 2015 and 2016. Moreover, they have had remarkable success at the local level obtaining government in several of Spain's main population centers. And the NPP in Taiwan formed in 2015 and successfully obtained the parliamentary seats in total in the 2016 elections. Both of these parties represent the third force in their respective parliaments.

Engagement was recorded as the summation of likes, comments, and reaction categories aggregated on a weekly basis. Reactions appeared as a response type in addition to likes in 2015, enabling users to signify their anger, surprise, laughter, and sadness in reaction to a post. The distribution of the engagement on the Facebook pages of these parties is displayed in Figures 1aand $1 \mathrm{~b}$ corresponding to the NPP and Podemos. 


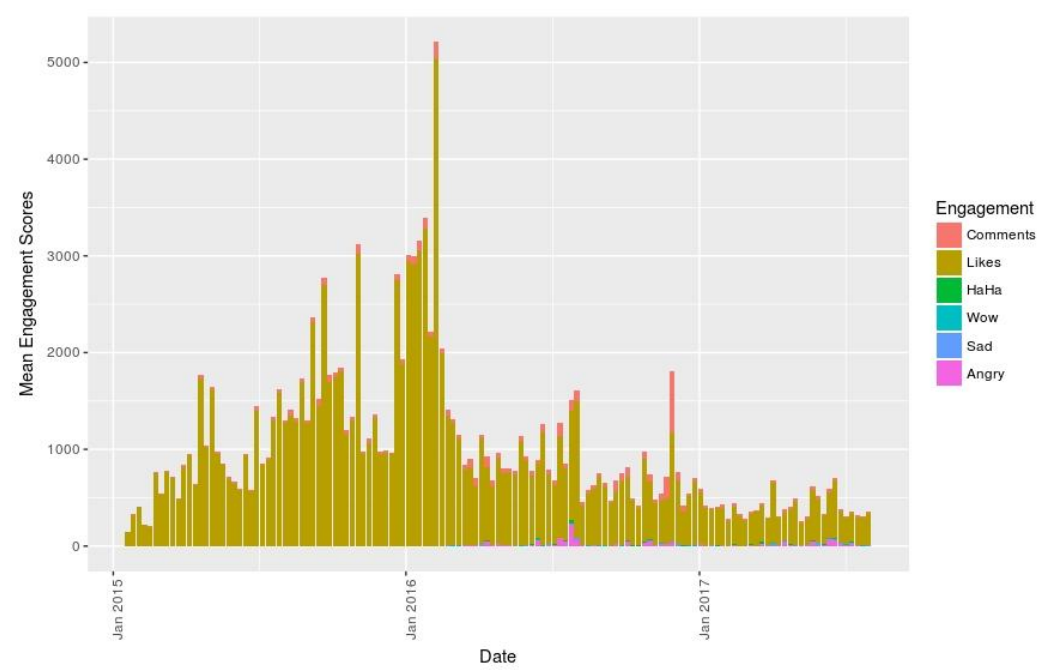

Figure1a. NPP Page Engagement over Time

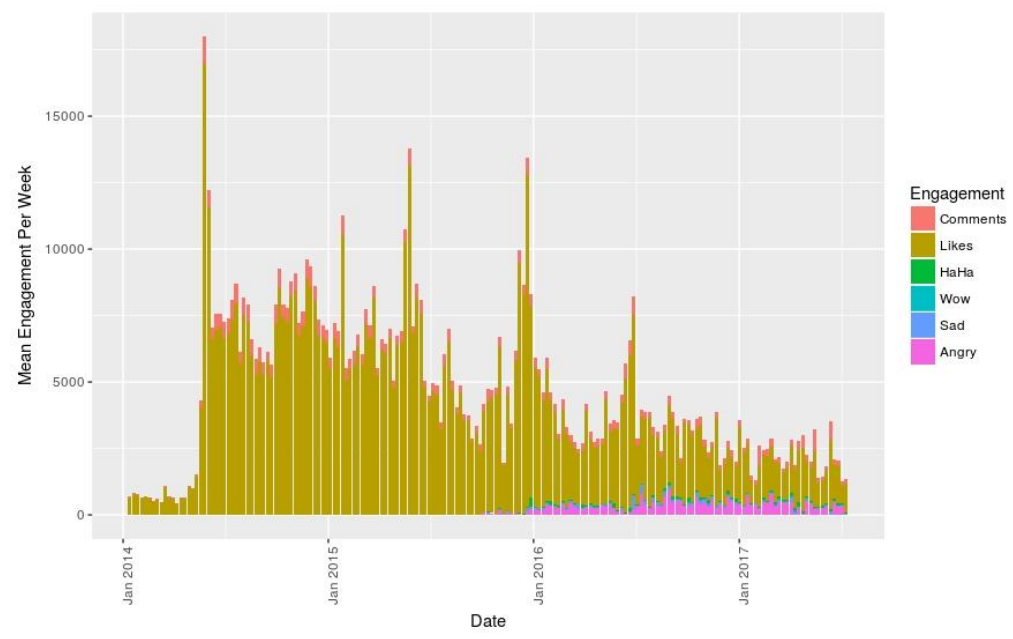

Figure1b. Podemos Facebook Page Engagement over Time

Both pages have a low level of commenting in relation to liking or other "clicktivist" forms of page engagement throughout the entire period. This corresponds with an early stage of party formation where visitors to the Podemos Facebook page mostly signal their support of the messaging of the party rather than contributing their own narratives and personalized frames. This electoral result led to a significant internal debate within the party as to whether they should become a pragmatic, officeseeking party, and work with the center-left Socialist Workers' Party of Spain (PSOE). Ultimately, the leadership challenge failed on the basis of a strategy to recommit to listening to "el pueblo" - the people in the towns who they were thought to have widely neglected in crafting professionalized electoral message (Casero-Ripollés, Feenstra, and Tormey 2016). It appears that beyond the slogans and promises, this period has indeed seen the rise of feedback in the form of commenting on party posts.

Last, the NPP formed in early 2015 and contested Taiwanese elections on January 16, 2016. Like the other parties, the early mobilization phase of the party formation is mostly characterized by post likes with little commentary. It is not until several months after the election in 2016 that the level of commenting picked up and this trend did not last long as in 2017, the comments all but disappear and the liking and emotional reactions decline below their level in 2015.

To more systematically analyze the level of commenting relative to the overall level of engagement, we consider the ratio between comments and likes over time for each of these Facebook pages. Although this metric ignores other "clicktivist" (Halupka 2014) reactions besides liking, we do so here for two reasons: first, these reactions were not possible early on which means that any metric would necessarily be biased if it included attributes which were only available for part of the time 
period of observation and, second, the level of emotional reactions is quite small making it unlikely that they drive a significant part of the story regarding the creation of supporter's narratives versus the legitimation of party narratives. The data for each of the parties is presented in Figures 2aand $2 \mathrm{~b}$ corresponding to the NPP and Podemos, respectively.

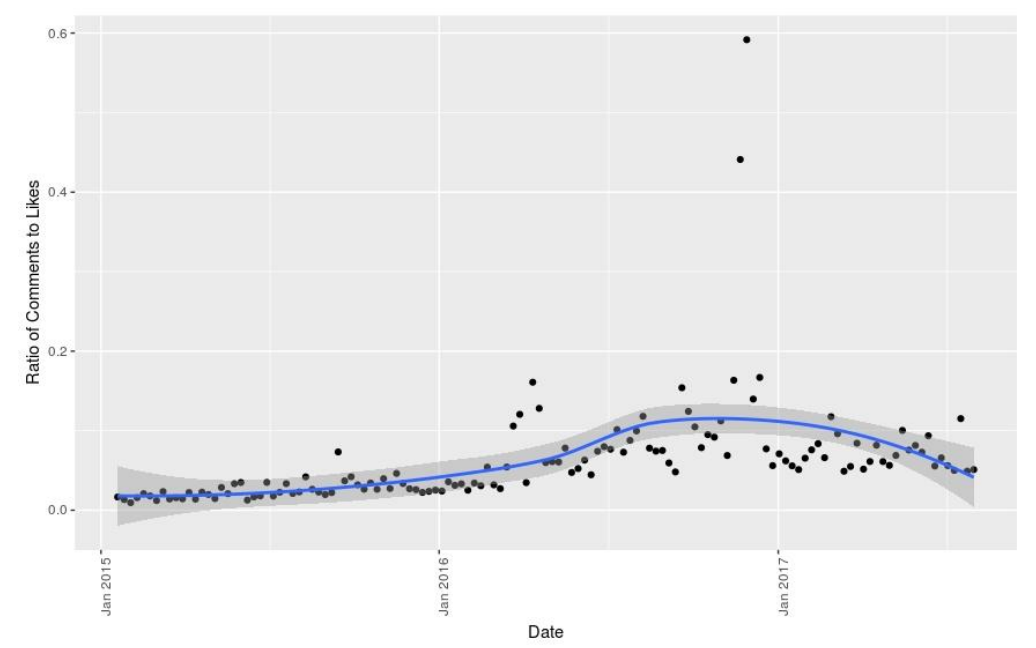

Figure2a. NPP Ratio of Comments to Likes over Time

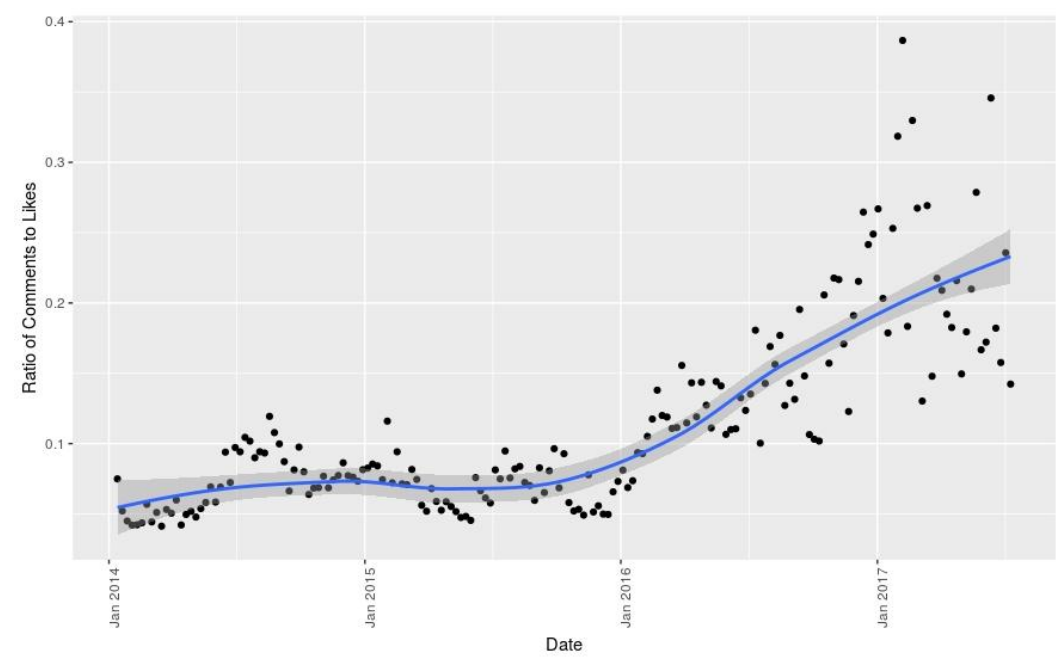

Figure2b. Podemos Comments to Likes Ratio over Time

Both parties start off with relatively low levels of commenting in relation to the liking of party posts. This suggests that far from being a highly deliberative environment in which these parties emerged, at least online, there is far more cheerleading than discussion. The ratio of comments to likes on the Podemos page was considerably lower throughout the existence of the party, only increasing after the December 20, 2015 election. This coincides with an extended period of the party searching for its identity after no party was able to form government and it decided to eventually forge an electoral alliance with a traditional far left party before contesting the June 2016 election during which they underperformed expectations. After the June 26, 2016 election, the ratio of comments to likes continued to grow as a leadership contest in the party unfolded. Still, this growth in the ratio of comments to likes coincides with a marked drop in overall engagement on the Podemos Facebook page which suggests that part of what drove the commenting was the significant decline in likes. Finally, the NPP page has had remarkably little commenting on it and by far the bulk of the engagement has come in the form of likes. The comment to like ratio remains near zero until the months after the 2016 election and it has since retreated to that low level of engagement.

The second aspect of the level of deliberation concerns how dominated the discussion is by a limited range of voices. To facilitate the understanding of the level of communications during the launch and campaign phases of the NPP and Podemos, the level of posts, comments, and replies are posted in Figures 3a-3d. 


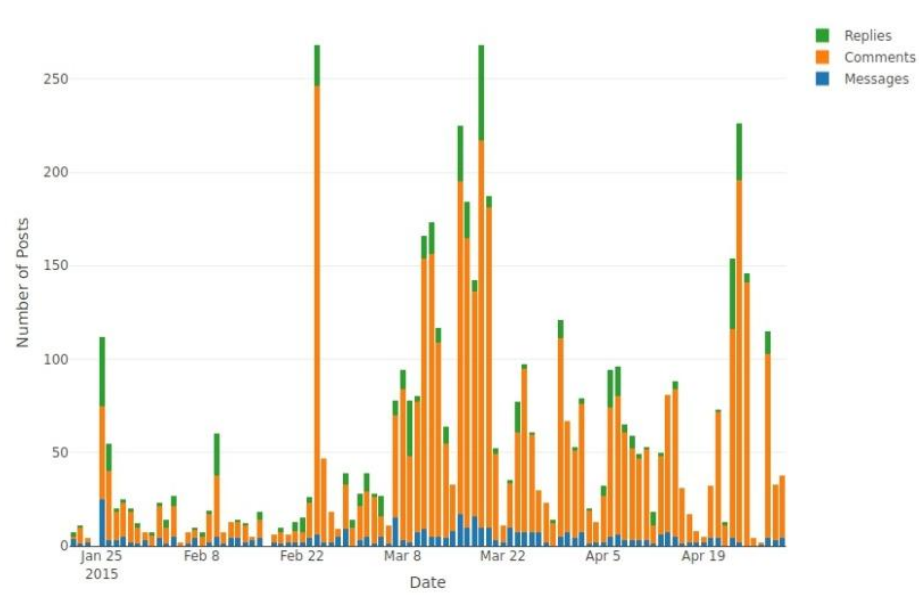

Figure3a. NPP Facebook Page Activity: First Three Months

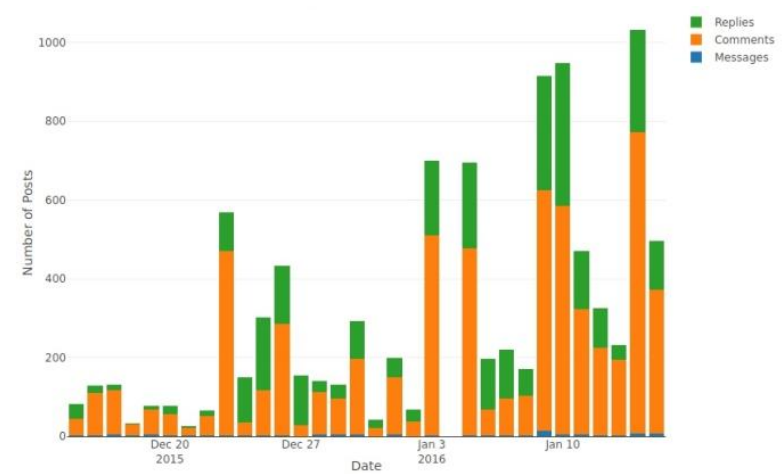

Figure3b. NPP Facebook Page Activity: First National Campaign

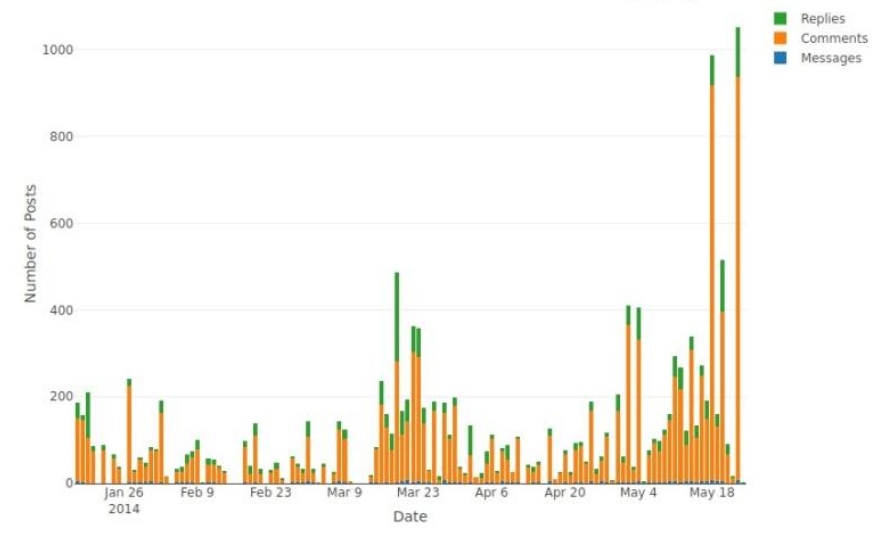

Figure3c. Podemos Facebook Page Activity: First Launch Phase

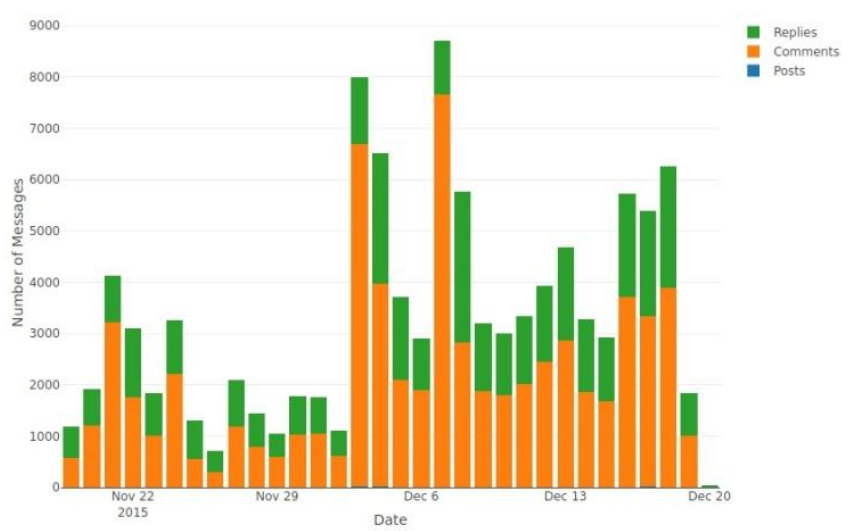

Figure3d. Podemos Facebook Page Activity First National Election Campaign 
These data show that during the campaign times, there is a substantially higher amount of engagement on the NPP's and Podemos's pages compared to their launch phases when the number of followers were likely much lower. ${ }^{1}$ Using concentration measures, we can calculate the level of concentration in comments on these pages during the party launch phase and during the first national campaign. These data are presented in Table 1. All three measures of concentration - the Gini coefficient, Theil's entropy, and Shannon's entropy - all point in the same direction. Despite differences in the structure of these political systems, we find that in both cases, the level of equality in engagement declines as the level of commenting increases during the campaign period. This difference is particularly pronounced on the Podemos page which saw the highest increases in commenting during the campaign period over the party launch phase.

Table1. Level of Concentration in Commenting

\begin{tabular}{|c|c|c|}
\hline & Party Launch & First National Campaign \\
\hline Podemos & & 0.511 \\
\hline Gini & 0.447 & 0.500 \\
\hline Thiel & 0.386 & 0.531 \\
\hline Entropy & 0.399 & 0.447 \\
\hline New Power Party & & 0.446 \\
\hline Gini & 0.441 & 0.403 \\
\hline Thiel & 0.424 & \\
\hline Entropy & 0.381 & \\
\hline
\end{tabular}

Finally, we consider the extent to which there is dialogue between the party and supporters and whether the level of dialogue decreases between the party launch and the entry into its first campaign. For Podemos, we determined party dialogue partners to include the Podemos page, Julio Iglesias (party leader), Iñigo Errejón (deputy and rival to Iglesias), Ana Castaño, Juan Carlos Monedero, Jaime Pastor, Santiago Alba Rico, Bibiana Medialdea, and Candido Gonzalez. These were ascertained as critical players in the party based on the party's Spanish Wikipedia page as Podemos and NPP activists have been known to be active on digital media platforms so this source seems a reasonable listing of key figures. In the case of the NPP, there were no replies to any comment by the party itself, its leader, or deputy leaders during either time period. There was more engagement by Podemos and its leadership. The proportion of comments from the party and its leadership was 0.028 during the launch of the party, a figure which dropped to 0.005 during its first campaign. A two-tailed t-test shows this change is statistically significant, $\mathrm{t}=8.442$ with a $\mathrm{p}$-value of 0.000 .

\section{DISCUSSION}

What do these data tell us in understanding the connectivity of parties? First, it helps differentiate parties with respect to the extent to which supporters confine their communications to legitimation of party messaging and whether they articulate their own takes on issues. Second, these data point to temporal differences as to the time periods when supporters of these parties are more or less likely to provide their own frames. When it comes to connective parties such as Podemos and NPP, the points where supporters provide the greatest input of their own communications appear after an election. Prior to that point, it may be that these parties do not attract significant discussion as they have emerged from the long periods of discussion which occurred during the movements which gave rise to the parties themselves. The Sunflower movement had arrived at the conclusion that Taiwanese politics required greater transparency and more opportunities for citizens to have a voice and a role in government over eight months prior to the foundation of the party. Similarly, Podemos emerged almost three years after sustained nation-wide protests which gave rise to discussion groups all over the country (Tormey 2015).

Theorigins of the NPP and Podemos from highly dialogical social movements (Borge and Satamarina 2015)may help explain the comparably small amount of supporter discussion during the early phases of these parties. However, after an election has passed, it is clear that supporters of these parties begin to reassess the state of the party. Given the overall declines in engagement with party Facebook pages after the election, it may be the case that only the most militant supporters of the party remain as the

\footnotetext{
${ }^{1}$ As these data were collected in 2017, it is not possible to go back and verify the number of followers on each page through publicly available data.
} 
window of mobilization during the campaign fades. During the initial launch phase we found some evidence that party organizations and leadership engage with supporters. That changes, however, when parties enter their first national campaigns and the level of dialogical engagement declines significantly while, although the level of engagement rises, commenting on their Facebook pages becomes more dominated by a smaller subset of voices.

Finally, we find some evidence that the institutional arrangements and party system matter. Taiwan has a very majoritarian system compared to Spain. We find little engagement outside of support for party messages on the NPP page. It may be the case as well that in Spain, the left-right cleavage of government-market relations has been more thoroughly institutionalized throughout the society in the form of labor unions and professional and market associations which means that this divide could remain more salient outside of periods of campaign activity as well as subject the politics of the day to greater sources of contestation. Further, it is not clear that the NPP's independence stance frames the issue in a manner which is radically different from that of the ruling Democratic Progressive Party, which may lead to a lack of need for NPP supporters to voice distinct and personalized frames on the matter.

The results are not conclusive. We have not yet determined systematically the kinds of frames that each of these parties and their supporters articulate. Further, there is a discussion about what democracy means in the Podemos comments, particularly in the wake of the 2016 election which proved to be a significant disappointment. And it was this discourse that was decisive in the leadership election in February 2017 (Jones 2017).

\section{REFERENCES}

[1] Almond, G. A, and S. Verba. 1989. The Civic Culture: Political Attitudes and Democracy in Five Nations. Sage Publications, Inc.

[2] Bakhtin, Mikhail Mikhaŭlovich. 1981. The Dialogic Imagination: Four Essays. University of Texas Press.

[3] Bang, Henrik Paul. 2003. Governance as Social and Political Communication. Manchester University Press.

[4] Bennett, W. Lance, and Alexandra Segerberg. 2013. The Logic of Connective Action: Digital Media and the Personalization of Contentious Politics. New York: Cambridge University Press.

[5] Bennett, W. Lance, Alexandra Segerberg, and Curd B. Knüpfer. 2017. "The Democratic Interface: Technology, Political Organization, and Diverging Patterns of Electoral Representation." Information, Communication \& Society 0(0): 1-26.

[6] Biezen, Ingrid van, and Thomas Poguntke. 2014. "The Decline of Membership-Based Politics." Party Politics 20(2): 205-16.

[7] Bimber, Bruce, Andrew Flanagin, and Cynthia Stohl. 2012. Collective Action in Organizations: Interaction and Engagement in an Era of Technological Change. 1st ed. Cambridge University Press.

[8] Borge, Rosa, and Eduardo Satamarina. 2015. "From the Streets into Institutionalization: Online Deliberative Practices in the New Parties in Catalonia and Spain." http://s3.amazonaws.com/academia.edu. documents/41346258/OnlineDel_Borge_Santamarina_Sardinia.pdf?AWSAccessKeyId=AKIAIWOWYY GZ2Y53UL3A\&Expires=1487573409\&Signature=S4n0tgOoyTuGHo0\%2BCInAlSz5n0w\%3D\&response -contentdisposition=inline\%3B\%20filename\%3DFrom_the_streets _into_ institutionalizati.pdf (February 20, 2017).

[9] Budge, Ian, and Hans Keman. 1993. Parties and Democracy: Coalition Formation and Government Functioning in Twenty States. Oxford University Press.

[10] Casero-Ripollés, Andreu, Ramón A. Feenstra, and Simon Tormey. 2016. "Old and New Media Logics in an Electoral Campaign The Case of Podemos and the Two-Way Street Mediatization of Politics." The International Journal of Press/Politics: 1940161216645340.

[11] Castells, Manuel. 2009. Communication Power. Oxford: Oxford University Press.

[12] Chadwick, Andrew, and Jennifer Stromer-Galley. 2016. "Digital Media, Power, and Democracy in Parties and Election Campaigns Party Decline or Party Renewal?" The International Journal of Press/Politics 21(3): 283-93.

[13] Chaffey, Dave. 2017. "Global Social Media Statistics Summary 2017.” Smart Insights. http://www.smartinsights.com/social-media-marketing/social-media-strategy/new-global-social-mediaresearch/ (June 8, 2017).

[14] Chen, Yi-Ling, and William Derhsing Li. 2011. "Neoliberalism, the Developmental State, and Housing Policy in Taiwan.” In Locating Neoliberalism in East Asia, eds. Bae-Gyoon Park, Richard Child Hill, and 
Asato Saito. Wiley-Blackwell, 196-224. http://onlinelibrary.wiley.com/doi/10.1002/9781444346657.ch8/ summary (July 24, 2017).

[15] Dahl, Robert A. 1957. "The Concept of Power.” Behavioral Science 2(3): 201-15.

[16] Dalton, Russell J. 1984. "Cognitive Mobilization and Partisan Dealignment in Advanced Industrial Democracies.” The Journal of Politics 46(1): 264-84.

[17] 2013. The Apartisan American: Dealignment and Changing Electoral Politics. CQ Press.

[18] Dalton, Russell J., David M. Farrell, and Ian McAllister. 2011. Political Parties and Democratic Linkage: How Parties Organize Democracy. OUP Oxford.

[19] Dalton, Russell J., and Martin P. Wattenberg. 2002. Parties without Partisans: Political Change in Advanced Industrial Democracies. Oxford University Press.

[20] Davis, Richard, Christina Holtz-Bacha, and Marion R. Just, eds. 2017. Twitter and Elections Around the World: Campaigning in 140 Characters or Less. New York, NY: Routledge.

[21] Dryzek, John S. 2009. "Democratization as Deliberative Capacity Building." Comparative Political Studies 42(11): 1379-1402.

[22] Easton, David. 1965. A Systems Analysis of Political Life. New York: John Wiley \& Sons.

[23] Enli, Gunn. 2015. The Routledge Companion to Social Media and Politics. Routledge.

[24] Freelon, Deen. 2017. "Campaigns in Control: Analyzing Controlled Interactivity and Message Discipline on Facebook.” Journal of Information Technology \& Politics 14(2): 168-81.

[25] Graham, Todd, Marcel Broersma, Karin Hazelhoff, and Guido van ’t Haar. 2013. "Between Broadcasting Political Messages and Interacting with Voters." Information, Communication \& Society 16(5): 692-716.

[26] Halupka, Max. 2014. "Clicktivism: A Systematic Heuristic.” 6(2): 115-32.

[27] Hindman, Matthew S. 2009. The Myth of Digital Democracy. Princeton: Princeton University Press.

[28] Ho, Ming-Sho, and Chun-Hao Huang. 2017. "Movement Parties in Taiwan, 1987-2016." Asian Survey 57(2): 343-67.

[29] Hsieh, John Fuh-sheng. 2005. "Ethnicity, National Identity, and Domestic Politics in Taiwan." Journal of Asian and African Studies 40(1-2): 13-28.

[30] Hsu, Jinn-yuh. 2009. "The Spatial Encounter between Neoliberalism and Populism in Taiwan: Regional Restructuring under the DPP Regime in the New Millennium.” Political Geography 28(5): 296-308.

[31] Inglehart, Ronald. 1970. “Cognitive Mobilization and European Identity." Comparative Politics 3(1): 4570 .

[32] Innis, Harold A. 2007. Empire and Communications. Toronto: Dundurn Press Ltd.

[33] Jensen, Michael J. 2017. "Social Media and Political Campaigning." The International Journal of Press/Politics 22(1): 23-42.

[34] Jensen, Michael J., and Henrik Bang. 2015. "Digitally Networked Movements as Problematization and Politicization.” Policy Studies 36(6): 573-89.

[35] Jensen, Michael J., and Henrik P. Bang. 2013. "Occupy Wall Street: A New Political Form of Movement and Community?" Journal of Information Technology \& Politics 10(4): 444-61.

[36] 2017. "Populism and Connectivism: An Analysis of the Sanders and Trump Nomination Campaigns.” Journal of Political Marketing 0(0): 1-22.

[37] Jones, Sam. 2017. "Podemos Leader Tightens Grip on Spanish Party after Landslide Re-Election." The Guardian. http://www.theguardian.com/world/2017/feb/12/podemos-pablo-iglesias-spain-re-electioninigo-errejon (August 30, 2017).

[38] Konieczny, Piotr. 2009. "Governance, Organization, and Democracy on the Internet: The Iron Law and the Evolution of Wikipedia.” Sociological Forum 24(1): 162-92.

[39] Kreiss, Daniel. 2012. Taking Our Country Back: The Crafting of Networked Politics from Howard Dean to Barack Obama. OUP USA.

[40] Liao, Da-chi, Boyu Chen, Michael J. Jensen, and Colin W. Pritchard. 2015. Political Behavior and Technology: Voting Advice Applications in East Asia. Palgrave Macmillan.

[41] Lijphart, Arend. 2012. Patterns of Democracy: Government Forms and Performance in Thirty-Six Countries. Yale University Press.

[42] Lipset, Seymour, and Stein Rokkan. 1967. "Cleavage Structures, Party Systems, and Voter Alignments: An Introduction.” In Party Systems and Voter Alignments: An Introduction, eds. Seymour Lipset and Stein Rokkan. New York: Free Press.

[43] Luhmann, Niklas. 1982. The Differentiation of Society. New York: Columbia University Press New York. [44] Mair, Peter. 2013. Ruling The Void: The Hollowing Of Western Democracy. London; New York: Verso. 
[45] McAllister, Ian. 2016. "Democratic Consolidation in Taiwan in Comparative Perspective." Asian Journal of Comparative Politics 1(1): 44-61.

[46] Michels, Robert. 1966. Political Parties: A Sociological Study of the Oligarchical Tendencies of Modern Democracy. New York: Simon and Schuster.

[47] Poguntke, Thomas et al. 2016. "Party Rules, Party Resources and the Politics of Parliamentary Democracies: How Parties Organize in the 21st Century." Party Politics 22(6): 661-78.

[48] Rigger, Shelley. 2016. "Kuomintang Agonistes: Party Politics in the Wake of Taiwan's 2016 Elections." Orbis 60(4): 488-503.

[49] Scarrow, Susan. 2015. Beyond Party Members: Changing Approaches to Partisan Mobilization. Oxford: Oxford University Press.

[50] Schattschneider, Elmer Eric. 1942. Party Government... Transaction Publishers.

[51] Stromer-Galley, Jennifer. 2014. Presidential Campaigning in the Internet Age. Oxford University Press.

[52] Thinking Taiwan. 2015. “The New Power Party's Platform.” http://thinking-taiwan.com/the-new-powerpartys-platform/ (February 9, 2016).

[53] Tormey, Simon. 2015. The End of Representative Politics. 1 edition. Malden, MA: Polity.

[54] Tsai, Chia-Hung. 2016. "Regional Divide and National Identity in Taiwan: Evidences from the 2012 Presidential Election.” Issues \& Studies 52(02): 1650007.

[55] Van Biezen, Ingrid, Peter Mair, and Thomas Poguntke. 2012. “Going, Going, . . Gone? The Decline of Party Membership in Contemporary Europe.” European Journal of Political Research 51(1): 24-56.

[56] Weeks, Brian E., Alberto Ardèvol-Abreu, and Homero Gil de Zúñiga. 2017. "Online Influence? Social Media Use, Opinion Leadership, and Political Persuasion." International Journal of Public Opinion Research 29(2): 214-39.

Citation: Da-chi Liao, Jiun-Chi Lin, Michael J. Jensen. "Is the Age of Party Democracy Over or Are Parties Entering a New Renaissance?”. International Journal of Political Science (IJPS), vol4, no.2, 2018, pp.15-26. doi:http://dx.doi.org/10.20431/2454-9452.0402002.

Copyright: (C) 2018 Authors. This is an open-access article distributed under the terms of the Creative Commons Attribution License, which permits unrestricted use, distribution, and reproduction in any medium, provided the original author and source are credited. 